\title{
PENINGKATAN HASIL BELAJAR MATEMATIKA \\ MELALUI PEMBELAJARAN PEMECAHAN MASALAH PADA SISWA KELAS I NKN A SMK NEGERI 3 PALOPO
}

\author{
Oleh: Hamid \\ Guru SMKN 3 Palopo
}

\begin{abstract}
Abstrak:
Penelitian ini termasuk penelitian tindakan kelas, yang diselidiki dalam penelitian ini adalah aplikasi metode pembelajaran pemecahan masalah dalam mengajarkan pokok bahasan matriks di kelas I NKN A SMK Negeri 3 Palopo. Populasi dalam penelitian ini adalah semua siswa kelas I NKN A SMK Negeri 3 Palopo pada Tahun Pelajaran 2012/2013 sejumlah 34 orang siswa. Penelitian ini bertujuan untuk mengetahui seberapa besar tingkat prestasi belajar siswa yang diajar dengan metode pemecahan masalah. Dari hasil penelitian diperoleh kesimpulan bahwa tingkat prestasi belajar siswa yang diajar melalui metode pemecahan masalah sangat baik.
\end{abstract}

Kata Kunci: Prestasi belajar, metode pemecahan masalah.

\section{Pendahuluan}

\section{A. Latar Belakang}

Masih rendahnya kualitas pendidikan di Indonesia memerlukan perhatian dan penanganan yang serius dari semua pihak agar dapat diatasi dan mencari jalan keluar yang tepat. Usaha peningkatan kualitas pendidikan merupakan tugas dan tanggungjawab semua pihak yang terkait baik pemerintah, masyarakat (orang tua/wali siswa), kepala sekolah, guru dan peserta didik. Kedudukan guru sebagai tenaga profesional berfungsi untuk meningkatkan martabat dan peran guru sebagai agen pembelajaran yang bertujuan untuk meningkatkan mutu pendidikan nasional (Pasal 4 UU No.14 Tahun 2005 tentang Guru dan Dosen). Guru sebagai agen pembelajaran dituntut untuk selalu kreatif dan inovatif terhadap penguasaan materi dan metodologi pembelajaran.

Dalam paradigma pembelajaran lama komunikasi cenderung berlangsung satu arah atau monoton, guru lebih mendominasi pembelajaran sehingga peserta didik merasa jenuh dan tersiksa. Oleh karena itu dalam pembelajaran matematika, guru hendaknya memilih berbagai variasi 
metode, strategi dan pendekatan yang tepat agar tujuan pembelajaran dapat dicapai sesuai dengan rencana. Karakteristik matematika yang bersifat abstrak membuat mereka kesulitan untuk belajar matematika lebih mendalam sehingga kemampuan menganalisis berbagai masalah dalam pembelajaran matematika masih kurang. Hal ini mengakibatkan hasil belajar siswa yang masih rendah. Perlu diketahui bahwa baik atau tidaknya suatu pemilihan model pembelajaran tergantung kepada tujuan pembelajaran, kesesuaian dengan materi pembelajaran, tingkat perkembangan peserta didik, kemampuan guru dalam mengelola pembelajaran serta mengoptimalkan sumbersumber belajar yang ada.

Strategi dan model pembelajaran yang dapat digunakan dalam pembelajaran antara lain strategi pembelajaran berdasarkan masalah (problem solving), pengajaran langsung, pembelajaran kontekstual, pembelajaran koperatif dan sebagainya. Pendekatan yang berpusat pada anak menekankan pentingnya menggunakan metode mengajar yang disesuaikan dengan sifat anak dan partisipasinya dalam proses pendidikan. Salah satu metode mengajar yang mempunyai kadar CBSA (Cara Belajar Siswa Aktif) tinggi yaitu metode mengajar pemecahan masalah. Pada proses belajar mengajar dengan pemecahan masalah dapat mengikutsertakan anak secara aktif karena pengorganisasian dan penyampaian materi sesuai dengan kesiapan mental anak didik.

Sesuai dengan pengamatan penulis baik secara langsung maupun melalui informasi guru dan siswa, rendahnya nilai matematika siswa mungkin disebabkan antara lain karena metode mengajar guru yang monoton dengan menggunakan metode konvensional yaitu ceramah, dimana guru mendominasi kegiatan belajar mengajar tanpa mengikut sertakan anak secara aktif didalamnya. Di SMK Negeri 3 Palopo, hasil belajar matematika siswa masih rendah jika dibandingkan dengan nilai mata pelajaran lainnya, ini berdasarkan nilai Laporan Hasil Belajar mereka pada semester I tahun pelajaran 2012/2013 yang rataratanya 59,49 . Hal ini disebabkan oleh beberapa faktor baik internal maupun eksternal siswa.

Berdasarkan pada latar belakang di atas, maka penulis bermaksud melakukan penelitian dengan judul: 
105 | al-Khwarizmi, Volume II, Edisi I, Maret 2014, Hal. 103 - 118

"Peningkatan Hasil Belajar Matematika Melalui Pembelajaran Pemecahan Masalah pada Siswa Kelas I NKN A SMK Negeri 3 Palopo".

\section{B. Rumusan Masalah}

Berdasarkan latar belakang, maka rumusan masalah dalam penelitian ini adalah: Apakah hasil belajar matematika siswa kelas I NKN A SMK Negeri 3 Palopo dapat ditingkatkan melalui pembelajaran pemecahan masalah?

\section{Manfaat Penelitian}

Hasil penelitian tindakan kelas ini dapat memberikan manfaat yang berarti kepada:

1) Guru: Sebagai acuan untuk mengarahkan dan membimbing siswa sehingga dapat mencapai hasil belajar matematika yang tinggi melalui penerapan metode pemecahan .

2) Siswa: Sebagai metode yang baik untuk memahami matematika dengan benar sehingga dapat menjadi pola belajar siswa dalam mempelajari matematika.

3) Sekolah: Dapat dijadikan model dalam pengajaran matematika untuk setiap jenjang kelas dan dapat diterapkan oleh guru-guru pada mata pelajaran lain.

\section{Pembahasan}

\section{A. Hakikat Matematika}

Pengertian matematika menurut kamus bahasa Indonesia adalah ilmu yang berkaitan dengan bilanganbilangan, ilmu hitung. Andi Hakim Nasution (1982) mengemukakan bahwa istilah "matematika" berasal dari kata Yunani yaitu "mathein" atau "mathenein" yang berarti "mempelajari". Mungkin juga kata itu erat hubungannya dengan kata Sansekerta "medha" atau "widya" yang artinya "kepandaian", "ketahuan" atau "intelegensi". Tinggih (Udin dkk., 1992) mengemukakan bahwa secara etimologis perkataan matematika berasal dari istilah matematis, berasal dari kata latin mathematica yang mulanya diambil dari kata Yunani "Mathematike" yang berarti "relating to learning". Perkataan itu mempunyai akar kata mathema yang berarti pengetahuan atau ilmu, kata kerja manthanein artinya belajar, jadi secara luas matematika adalah ilmu tentang cara mempelajari ilmu pengetahuan.

Sedangkan R. Surdjadi (2000) berpendapat bahwa matematika adalah cabang ilmu pengetahuan eksak dan 
terorganisir secara sistimatis. Matematika adalah pengetahuan tentang bilangan dan kalkulasi. Matematika adalah pengetahuan tentang penalaran logis dan berhubungan dengan bilangan. Matematika adalah pengetahuan tentang fakta-fakta kuantitatif dan masalah tentang ruang dan bentuk. Matematika adalah pengetahuan tentang struktur yang logis.

\section{B. Pengertian Belajar dan Hasil Belajar}

1. Pengertian Belajar

Dalam kamus bahasa Indonesia, belajar berarti berusaha untuk memperoleh ilmu atau menguasai keterampilan (berlatih). Belajar menurut pengertian secara psikologis adalah suatu proses perubahan tingkah laku sebagai hasil interaksi dengan lingkungannya dalam memenuhi kebutuhan hidupnya. Adapun pengertian belajar menurut pendapat para ahli sebagai berikut:

a. Gagne (1977); Belajar adalah proses perubahan tingkah laku yang meliputi perubahan kecenderungan manusia seperti sikap, minat dan nilai perubahan kemampuan yakni peningkatan kemampuan untuk melakukan berbagai jenis performance (kinerja).

b. Slameto (1987); Belajar adalah suatu proses usaha yang dilakukan individu untuk memperoleh suatu perubahan tingkah laku yang secara keseluruhan sebagai hasil pengalaman individu itu sendiri dalam interaksi dengan lingkungannya.

c. The Liang Gie (1988); Belajar adalah segenap rangkaian aktivitas yang dilakukan secara sadar oleh sesorang yang mengakibatkan perubahan dalam dirinya berupa perubahan dalam pengetahuan atau kemahiran yang sifatnya relatif permanen.

d. Hudoyo (1990); Belajar adalah merupakan suatu usaha yang berupa kegiatan lain yang terjadi perubahan tingkah laku yang relatif/tetap. Perubahan tingkah laku ditandai oleh kemampuan peserta didik mendemonstrasikan pengetahuan dan keterampilannya.

e. Gredler (1994); Belajar adalah proses memperoleh berbagai kecakapan, keterampilan dan sikap.

Berdasarkan pegertian belajar tersebut disimpulkan bahwa belajar adalah suatu aktivitas yang dilakukan secara sadar untuk memperoleh kecakapan, keterampilan dan perubahan sikap atau tingkah laku seseorang. 


\section{Pengertian Hasil Belajar}

Dalam kamus bahasa Indonesia, hasil diartikan sebagai sesuatu yang didapat dari jerih payah atau sesuatu yang dicapai dari yang telah dilakukan atau dikerjakan sebelumnya. Bahri (1994) mengemukakan bahwa hasil adalah sesuatu yang diperoleh dari kegiatan yang dikerjakan, diciptakan, baik secara individual maupun kelompok. Jadi hasil menunjuk sesuatu yang dicapai seseorang setelah melakukan usaha atau kegiatan. Jika dikaitkan dengan belajar maka hasil menunjuk sesuatu yang dicapai seseorang yang belajar dalam kurung waktu tertentu.

Selanjutnya dikutip pendapat para ahli tentang pengertian hasil belajar antara lain :

a. Briggs (1979); Hasil belajar adalah seluruh kecakapan dan segala hal yang diperoleh melalui proses belajar mengajar di sekolah yang dinyatakan dengan angka dan diukur dengan menggunakan tes hasil belajar.

b. Hudoyo (1990); Hasil belajar adalah proses berpikir menyusun hubungan-hubungan antara bagian-bagian interaksi yang telah diperoleh sebagai pengertian karena itu orang jadi memahami dan menguasai hubunganhubungan tersebut sehingga orang itu dapat menampilkan pemahaman dan penguasaan bahan pelajaran yang dipelajari.

c. Soedijarto (1993); Hasil belajar adalah tingkat penguasaan yang dicapai oleh pelajar dalam mengikuti program belajar mengajar sesuai dengan tujuan pendidikan yang ditetapkan.

d. Sudjana (2004); Hasil belajar adalah kemampuankemampuan yang dimiliki siswa setelah ia menerima pengalaman belajar.

e. Sukmadinata (2005); Hasil belajar (achievement) merupakan realisasi atau pemekaran dari kecakapan potensial atau kapasitas yang dimiliki seseorang.

Dalam sistem pendidikan nasional, rumusan tujuan pendidikan baik tujuan kurikuler maupun tujuan instruksional menggunakan klasifikasi hasil belajar dari Benyamin Bloom yang secara garis besar membagi tujuan tersebut kedalam tiga ranah yaitu ranah kognitif, ranah afektif dan ranah psikomotor. Ranah kognitif berkenaan dengan hasil belajar intelektual, ranah afektif berkenaan dengan hasil belajar sikap atau tingkah laku sedangkan ranah psikomotor 
berkenaan dengan hasil belajar keterampilan dan kemampuan bertindak. Di sekolah hasil belajar dapat tergambar dari penguasaan siswa terhadap materi-materi pelajaran yang ditempuhnya melalui tes hasil belajar.

\section{Metode Mengajar}

Metode mengajar menurut Hudoyo (1979) adalah suatu cara atau teknik mengajar topik-topik tertentu yang disusun secara teratur dan logis.

\section{Metode Konvensional}

Menurut Gulo (2002), ceramah merupakan satu-satunya metode konvensional dan masih tetap digunakan dalam strategi belajar mengajar. Metode ceramah merupakan suatu metode penyampaian informasi dimana guru berbicara secara aktif sedangkan peserta didik mendengarkannya. Hudoyo (1979) mengemukakan bahwa ciri metode ceramah adalah guru berbicara terus-menerus di depan kelas sedangkan para siswa sebagai pendengar. Metode ini merupakan bentuk belajar mengajar satu arah. Dalam proses belajar mengajar dengan metode ceramah, guru tidak memberikan bimbingan secara individu bagi siswa yang mengalami kesulitan menyelesaikan tugas.

Berdasarkan uraian di atas, dapat disimpulkan bahwa yang dimaksud dengan pembelajaran matematika secara konvensional adalah pembelajaran dengan ceramah yang sering digunakan oleh guru matematika pada umumnya.

2. Motode Pemecahan Masalah (Problem Solving)

Hudoyo (1990) mengatakan suatu pertanyaan merupakan masalah bagi seseorang, bila orang itu tidak memiliki aturan hukum tertentu yang dapat digunakan untuk menentukan jawaban pertanyaan tersebut. Menurut Muhkal (1999), suatu pertanyaan merupakan masalah, jika pertanyaan itu menyajikan suatu tantangan dan tidak dapat diselesaikan dengan cara-cara yang rutin. Selain itu, suatu pertanyaan yang menantang merupakan masalah bagi seseorang, bila orang itu menerima tantangan tersebut. Dari definisi tersebut, dapat dikatakan bahwa suatu masalah merupakan suatu kondisi dimana seseorang membutuhkan sesuatu, tetapi ia tidak mengetahui dengan segera langkahlangkah apa yang dapat dilakukan untuk memenuhinya.

Branca (1980) menyatakan bahwa istilah pemecahan masalah mempunyai pengertian yang berbeda menurut waktu dan individu. Pemecahan masalah dalam matematika 
meliputi penyelesaian soal cerita, menyelesaikan soal yang tidak rutin, mengaplikasikan matematika dalam kehidupan sehari-hari atau kondisi lain, membuktikan dan menciptakan. Selanjutnya, Sumarno (1994) mengemukakan bahwa pemecahan masalah menekankan pada tiga hal yaitu meningkatkan sikap positif siswa terhadap matematika, mendorong siswa berpartisipasi aktif dan menggiring siswa pada keterampilan yang menantang sehingga siswa terlatih untuk berpikir analitis. Mulbar (2000) mengemukakan pemecahan masalah relevan dengan proses belajar mengajar yaitu sebagai latihan rutin yang dilakukan terhadap siswa untuk menumbuhkan dan mengukur kemampuan siswa terhadap suatu materi yang telah diberikan. Mengajar dengan menggunakan metode pemecahan masalah adalah cara mengajar dengan membimbing siswa untuk menyelesaikan soal dengan langkah yang jelas. Muhkal (1999) mengemukakan bahwa banyaknya langkah yang perlu ditempuh dalam menyelesaikan suatu masalah, tergantung dari tingkat kesukaran dan kemampuan yang dimiliki oleh seseorang yang menyelesaikan masalah.

Langkah-langkah dalam menyelesaikan masalah matematika sebagai berikut:

1) Memahami masalah

a. Memahami dengan rinci dan eksplisit

b. Apa yang diketahui

c. Apa yang ditanyakan atau yang dicari, dan

d. Apa syarat-syarat yang harus dipenuhi

2) Membuat rencana penyelesaian/mencari alternative penyelesaian

a. Mencari hubungan antara apa yang ditanyakan dengan apa yang ketahui

b. Apakah pernah melihat masalah yang serupa?

c. Apakah masalah yang pernah dilihat ada kaitannya dengan masalah tersebut.

3) Melaksanakan rencana penyelesaian/melakukan perhitungan

a. Memeriksa atau meneliti setiap langkah.

b. Apakah setiap langkah yang dilakukan sudah benar?

c. Apakah langkah yang benar itu dapat ditunjukkan benarnya.

4) Mengevaluasi kembali penyelesaian yang sudah dilakukan /memeriksa ulang hasil perhitungan. 
Kekurangan dan kelebihannya dikemukakan oleh Bitman (Munir, 2003) adalah: (1). Kelebihan: Belajar metode pemecahan masalah adalah belajar penuh makna, dapat menimbulkan motivasi, siswa belajar transfer konsep dan prinsip matematika ke situasi baru, Mengajak siswa berpikir rasional dan siswa lebih aktif. (2). Kekurangan: Memerlukan waktu yang lama, dapat menimbulkan frustasi jika penyajiannya terlalu cepat, kurang cocok bagi siswa dengan kemampuan rendah, dan dibutuhkan guru yang mempunyai kesabaran dalam menggunakan metode ini.

Dengan metode pemecahan masalah, siswa akan belajar mengembangkan model-model untuk soal tertentu dan tidak takut kepada soal-soal yang menantang. Dengan demikian pemecahan masalah perlu diajarkan pada siswa agar mampu dan terampil dalam menganalisis suatu informasi untuk mengambil suatu kesimpulan yang tepat.

\section{Hipotesis Tindakan}

Berdasarkan kerangka teoritik di atas, maka hipotesis tindakan penelitian ini adalah: hasil belajar matematika siswa dapat ditingkatkan bila metode pemecahan masalah diterapkan dalam pembelajaran matematika.

\section{Metode Penelitian \\ A. Setting Penelitian}

Penelitian ini dilaksanakan di kelas I NKN A SMK Negeri 3 Palopo tahun pelajaran 2008/2009 yang berjumlah 34 orang siswa yaitu terdiri dari 32 laki-laki dan 2 perempuan.

\section{B. Faktor yang Diselidiki}

Faktor yang ingin diselidiki dalam penelitian ini yaitu:

1. Faktor siswa: melihat kemampuan dalam memahami masalah, membuat rencana penyelesaian, melaksanakan rencana penyelesaian, dan mengevaluasi kembali penyelesaian yang sudah dilakukan dalam pembelajaran dengan menggunakan metode pemecahan masalah.

2. Faktor sumber pelajaran: yaitu memperhatikan sumber atau bahan pelajaran yang digunakan apakah sudah sesuai dengan tujuan yang hendak dicapai, demikian pula dengan metode pemecahan masalah, apakah problem bahan pelajaran matematika dapat dinyatakan lebih terpecahkan. 


\section{Rencana Tindakan}

Penelitian tindakan kelas ini dilaksanakan dalam dua siklus dengan rincian sebagai berikut:

1. Siklus I

a) Perencanaan Tindakan

1) Menelaah kurikulum matematika SMK Kelas I.

2) Membuat skenario pembelajaran.

3) Membuat lembar observasi untuk melihat kondisi proses belajar mengajar berlangsung di kelas ketika metode tersebut diaplikasikan.

4) Melaksanakan tes akhir untuk melihat perkembangan siswa setelah metode pemecahan masalah diaplikasikan.

b) Pelaksanaan Tindakan

1) Penyajian materi pelajaran dimulai dari yang sederhana diusahakan setiap langkah dapat mengarahkan kegiatan siswa pada inti permasalahan berdasarkan metode pemecahan masalah.

2) Pada saat penerapan, guru memberikan contoh menyelesaikan permasalahan matematika.

3) Siswa menyelesaikan soal latihan yang telah ditentukan oleh guru.

4) Guru berkeliling membimbing dan mengawasi serta langsung menilai apakah pekerjaan siswa sudah benar atau perlu diperbaiki.

5) Pada setiap akhir pertemuan ditarik kesimpulan dan guru memberikan PR.

6) Pada akhir siklus I diadakan ulangan harian.

c) Observasi

Observasi dilakukan terhadap pelaksanaan tindakan dengan menggunakan lembar observasi yang telah disiapkan, semua kejadian dicatat oleh peneliti.

d) Refleksi

Pada akhir siklus diadakan refleksi terhadap data hasil observasi yang diperoleh selama penelitian berlangsung yang kemudian dianalisis. Kekurangan-kekurangan yang terjadi pada siklus I diperbaiki pada siklus berikutnya.

2. Siklus II

a) Perencanaan Tindakan

Pada siklus II dilanjutkan program pengajaran dengan langkah-langkah yang sama pada siklus I. 
b) Pelaksanaan Tindakan

1. Guru tetap menjelaskan konsep secara klasikal sesuai dengan skenario yang telah dibuat, dan tetap menggunakan metode pemecahan masalah.

2. Siswa mengerjakan soal latihan.

3. Soal-soal yang dianggap sukar dibahas secara klasikal.

4. Pada akhir siklus II diberikan ulangan harian kedua kemudian memberi kesempatan kepada siswa menulis tanggapan mengenai pelaksanaan tindakan.

c) Observasi

Observasi yang dilakukan pada siklus ke II sama dengan observasi yang dilakukan pada siklus I, semua kejadian penting dicatat pada lembar observasi.

d) Refleksi

Refleksi dilakukan pada akhir siklus. Hasil yang diperoleh pada tahap observasi dikumpulkan serta dianalisis.

\section{Teknik Pengumpulan Data}

Adapun teknik pengumpulan data yang dilakukan dalam penelitian ini adalah sebagai berikut:

1. Data mengenai tingkat penguasaan siswa terhadap materi pelajaran dikumpulkan dengan menggunakan tes pada akhir setiap siklus dalam bentuk ulangan harian.

2. Data mengenai keaktifan siswa diambil melalui observasi selama proses pembelajaran.

3. Data mengenai pelaksanaan tindakan dikumpulkan dengan memberi kesempatan siswa menuliskan tanggapan pada akhir siklus II.

\section{E. Teknik Analisis Data}

Data yang terkumpul selanjutnya di analisis dengan menggunakan analisis kuantitatif dan analisis kualitatif. Untuk keperluan analisis kualitatif akan digunakan teknik pengkategorian tingkat penguasaan hasil belajar matematika yang lazim digunakan oleh beberapa peneliti tindakan kelas yaitu tingkat penguasaan siswa $0-34$ dikategorikan sangat rendah, 35 - 54 dikategorikan rendah, 55-64 dikategorikan sedang, 65 - 84 dikategorikan tinggi dan 85 - 100 dikategorikan sangat tinggi. 
113 | al-Khwarizmi, Volume II, Edisi l, Maret 2014, Hal. 103 - 118

\section{F. Indikator Keberhasilan}

Indikator keberhasilan penelitian ini adalah bila terjadi peningkatan nilai rata-rata hasil belajar matematika siswa kelas I NKN A SMK Negeri 3 Palopo setelah pembelajaran melalui metode pemecahan masalah.

\section{Hasil Penelitian dan Pembahasan}

Hasil penelitian ini dapat dilihat dalam Tabel 4.a sampai dengan Tabel 4.d berikut ini:

Tabel 4.a.Deskripsi Nilai Hasil Belajar Matematika Siswa setelah
Pembelajaran dengan Pemecahan Masalah pada Siklus I.
\begin{tabular}{|c|c|}
\hline Statistik & Nilai Statistik \\
\hline Subjek & 34 \\
Nilai Tertinggi & 90 \\
Nilai Terendah & 28 \\
Rentang Nilai & 62 \\
Nilai Rata-rata & 59,74 \\
Median & 55 \\
Standar Deviasi & 16,17 \\
\hline
\end{tabular}

Tabel 4.b.Distribusi Frekuensi Hasil Belajar Matematika Siswa setelah Pembelajaran dengan Pemecahan Masalah pada Siklus I.

\begin{tabular}{|c|c|c|c|c|}
\hline No. & Nilai & Kategori & Frekuensi & Persentase \\
\hline 1. & $0-34$ & Sangat rendah & 3 & 8,88 \\
\hline 2. & $35-54$ & Rendah & 9 & 26,47 \\
\hline 3. & $55-64$ & Sedang & 10 & 29,41 \\
\hline 4. & $65-84$ & Tinggi & 6 & 17,65 \\
\hline 5. & $85-100$ & Sangat tinggi & 6 & 17,65 \\
\hline \multicolumn{3}{|c|}{ Jumlah } & 34 & 100 \\
\hline
\end{tabular}

Diketahui nilai rata-rata hasil belajar matematika siswa sebesar 59,74, jika dimasukkan dalam Tabel 4.b. di atas ternyata berada dalam kategori sedang. Hal ini berarti bahwa tingkat hasil belajar matematika siswa kelas I NKN A SMK Negeri 3 Palopo setelah pembelajaran dengan pemecahan masalah berada dalam kategori sedang.

Tabel 4.c.Deskripsi Nilai Hasil Belajar Matematika Siswa setelah Pembelajaran dengan Pemecahan Masalah pada Siklus II.

\begin{tabular}{|c|c|}
\hline Statistik & Nilai Statistik \\
\hline Subjek & 34 \\
Nilai Tertinggi & 100 \\
\hline
\end{tabular}




\begin{tabular}{|c|c|}
\hline Nilai Terendah & 30 \\
Rentang Nilai & 70 \\
Nilai Rata-rata & 70,35 \\
Median & 70 \\
Standar Deviasi & 15,57 \\
\hline
\end{tabular}

Tabel 4.d.Distribusi Frekuensi Hasil Belajar Matematika Siswa setelah

Pembelajaran dengan Pemecahan masalah pada Siklus II.

\begin{tabular}{|c|c|c|c|c|}
\hline No. & Nilai & Kategori & Frekuensi & Persentase \\
\hline 1. & $0-34$ & Sangat rendah & 2 & 5,88 \\
\hline 2. & $35-54$ & Rendah & 1 & 2,94 \\
\hline 3. & $55-64$ & Sedang & 5 & 14,71 \\
\hline 4. & $65-84$ & Tinggi & 20 & 58,82 \\
\hline 5. & $85-100$ & Sangat tinggi & 6 & 17,65 \\
\hline \multicolumn{3}{|c|}{ Jumlah } & 30 & 100 \\
\hline
\end{tabular}

Dari Tabel 4.c. diketahui nilai rata-rata hasil belajar matematika siswa sebesar 70,54 jika dimasukkan dalam Tabel 4.d. di bawah ternyata berada dalam kategori tinggi. $\mathrm{Hal}$ ini berarti bahwa tingkat hasil belajar matematika siswa kelas I NKN SMK Negeri 3 Palopo setelah pembelajaran dengan pemecahan masalah berada dalam kategori tinggi.

Siswa yang berada dalam tingkat penguasaan sangat rendah dan rendah disebabkan mereka malas belajar dan malu bertanya. Sedangkan siswa yang berada dalam tingkat penguasaan tinggi dan sangat tinggi diantaranya disebabkan karena motivasi dan minat belajar yang tinggi.

Dari nilai rata-rata siswa setelah pembelajaran dengan pemecahan masalah pada siklus I dan siklus II terlihat bahwa hasil belajar matematika siswa kelas I NKN A SMK Negeri 3 Palopo mengalami peningkatan. Hal ini terlihat pada siklus I hasil belajar siswa berada dalam kategori sedang, sedangkan pada siklus II hasil belajar siswa berada dalam kategori tinggi. Ini berarti terjadi peningkatan hasil belajar matematika siswa kelas I NKN A SMK Negeri 3 Palopo, dari kategori sedang menjadi kategori tinggi.

Selama penelitian pada siklus I dan siklus II tercatat sejumlah perubahan yang terjadi pada sikap siswa terhadap pelajaran matematika. Perubahan tersebut meliputi:

a) Minat belajar matematika siswa semakin tinggi ditandai sejumlah siswa yang hadir pada setiap kali pertemuan semakin meningkat. 
b) Keberanian siswa untuk menjawab pertanyaan lisan guru mengalami peningkatan, ditandai sejumlah siswa yang mengacungkan tangan untuk memberikan jawaban.

c) Perhatian siswa pada proses belajar mengajar dari siklus I sampai siklus II meningkat, ditandai semakin banyaknya siswa yang bertanya tentang materi pelajaran yang belum mereka mengerti.

d) Perhatian siswa pada proses belajar mengajar dari siklus I sampai Siklus II meningkat, ditandai banyaknya siswa yang aktif mengerjakan tugas di sekolah.

e) Kesungguhan siswa dalam mengerjakan setiap soal latihan mengalami peningkatan, ditandai dengan banyaknya siswa yang meminta bimbingan dalam mengerjakan soal latihan.

f) Rasa percaya diri siswa meningkat ditandai dengan bertambahnya siswa yang berani tampil untuk mengerjakan soal di depan kelas.

g) Kesungguhan siswa dalam mengerjakan setiap soal latihan mengalami peningkatan, ditandai dengan banyaknya siswa yang mengumpulkan tugas tepat waktu.

Refleksi pada siklus I adalah sebagai berikut: pada pertemuan pertama penelitian kegiatan belajar mengajar hampir sama dengan kegiatan sebelum penelitian. Namun pada saat proses belajar mengajar siswa diberi kesempatan untuk menanyakan hal-hal yang belum dimengerti atas penjelasan guru, umumnya tidak ada yang mengacungkan tangan untuk bertanya dengan alasan sudah jelas, meskipun pada kenyataannya belum mengerti. Siswa pada umumnya pasif. Jika guru melontarkan pertanyaan, siswa tampak lebih berani untuk memberikan jawaban lisan secara bersamasama tanpa ingin diketahui dari mana sumber jawaban tersebut. Pada saat dijelaskan langkah-langkah pemecahan masalah, secara teoritis nampaknya seluruh siswa dapat mengetahuinya. Namun setelah diberikan soal yang harus diselesaikan, sebagian besar siswa telah mampu pada tahap apa yang diketahui dan apa yang ditanyakan dari soal, namun belum mampu menyelesaikannya hingga tuntas. Dalam proses belajar mengajar siswa belum terlalu aktif, banyak siswa yang tidak mengerjakan tugas, ada juga siswa yang minta izin keluar dengan alasan buang air kecil. Menyadari keadaan tersebut maka pada pertemuan berikutnya, penulis mengambil beberapa tindakan 
diantaranya membimbing siswa dalam menyelesaikan soalsoal dengan menggunakan metode pemecahan masalah.

Refleksi pada siklus II adalah sebagai berikut: pelaksanaan penelitian pada siklus II pada dasarnya sama dengan pada penelitian siklus I. Pada pertemuan pertama hingga pertemuan akhir siklus II siswa mulai aktif belajar ini terlihat dengan banyaknya siswa yang mengajukan pertanyaan-pertanyaan untuk materi yang tidak mereka mengerti serta memberikan tanggapan dan komentar saat mereka membahas soal secara bersama-sama, bahkan banyak siswa yang mengerjakan tugas dikelas dan berlomba-lomba maju kepapan tulis untuk mengerjakan soal yang diberikan.

Dari hasil analisis terhadap refleksi siswa tentang pembelajaran melalui metode pemecahan masalah dapat disimpulkan bahwa pada umumnya siswa menyatakan penggunaan metode pemecahan masalah dalam pembelajaran matematika dapat membangkitkan motivasi dan minat belajar mereka. Hal ini dikarenakan materi yang disampaikan masih merupakan masalah, sehingga siswa merasa tertantang dan termotivasi untuk memecahkan masalah tersebut. Selain itu siswa selalu diberi kesempatan untuk menanyakan materi yang belum di mengerti sebelum materi lain dijelaskan lebih lanjut oleh guru. Beberapa siswa juga berpendapat bahwa pembelajaran dengan pemecahan masalah dapat membantu siswa menyelesaikan soal-soal latihan, sebab siswa dibimbing menyelesaikan soal tersebut dengan langkah-langkah pemecahan masalah. Langkahlangkah pemecahan masalah membuat siswa lebih cepat dan terampil dalam menyelesaikan soal-soal latihan.

\section{Penutup}

\section{A. Kesimpulan}

Kesimpulan dalam penelitian ini adalah sebagai berikut:

1. Terjadi peningkatan skor rata-rata hasil belajar pada siswa kelas I NKN A SMK Negeri 3 Palopo dari siklus I ke siklus II yaitu dari 59,74 menjadi 70,35. Dan peningkatan jumlah siswa yang tuntas belajarnya dari 13 orang (38,24\%) menjadi 26 orang (76,47\%).

2. Penggunaan metode pemecahan masalah dalam pembelajaran matematika dapat membangkitkan motivasi 
117 | al-Khwarizmi, Volume II, Edisi l, Maret 2014, Hal. 103 - 118

dan minat siswa untuk lebih meningkatkan prestasi belajar mereka.

\section{B. Saran}

Berdasarkan hasil yang diperoleh dari penelitian maka dalam rangka peningkatan hasil belajar matematika siswa dikemukakan beberapa saran sebagai berikut:

1. Untuk meningkatkan hasil belajar matematika, siswa harus dilibatkan dalam proses pembelajaran sehingga tercipta kemandirian dalam memecahkan masalah, sehingga pembelajaran dengan metode pemecahan masalah merupakan salah satu strategi alternatif.

2. Sebagai tindak lanjut penggunaan metode pemecahan masalah pada saat proses pembelajaran, diharapkan kepada guru untuk senantiasa memberikan tugas tambahan dirumah.

\section{DAFTAR PUSTAKA}

Nasution, Andi Hakim, 1982. Landasan Matematika. Jakarta: Barata-Fajar

Branca,1980. Problem Solving in School Mathematics.

Stanford University: Jhon Wiley dan Sons.

Briggs,1979. Instructional Design: Principles and Aplication.

Englewood-Cliffs,New Jersey: Prentice-Hall,Inc.

Gagne, 1970. Condition of Learning. New York: Holt Reinehart \& Wiston,Inc.

Gredler, 1994. Learning and Insruction, Theory Into Practice.

New York : Macmillan Pubhlising Co.

Hudoyo, H. 1979. Pengembangan Kurikulum Matematika dan Pelaksanaannya di Depan Kelas. Surabaya: Usaha Nasional.

Hudoyo, H. 1990. Strategi Mengajar Belajar Matematika. Malang: IKIP Malang.

Gulo, 2002. Strategi Belajar Mengajar. Jakarta : Gramedia Widiasarana Indonesia.

Muhkal, M. 1999. Menumbuhkan Kemampuan Mengajar Matematika. Eksponen Jurnal Pendidikan Matematika. Vol. 2 No. 1.

Mulbar, U. 2000. Suatu Pemahaman Berpikir secara Matematik. Eksponen Jurnal Pendidikan Matematika, 2(3), 215-224. 
Munir. 2003. Meningkatkan Hasil Belajar Matematika Melalui Pembelajaran dengan Metode Pemecahan masalah Kelas I SMP Negeri 3 Galesong Selatan Kabupaten Takalar. Skripsi FMIPA UNM Makassar.

Sujana, 2004, Teori-Teori Belajar Untuk Pengajaran. Jakarta: FEUI

Slameto. 1987. Belajar dan Faktor-faktor yang Mempengaruhinya. Jakarta: Bina Aksara.

Sudijarto,1993. Menuju Pendidikan Nasional yang Relevan dan Bermutu. Jakarta: Balai Pustaka.

Sukmadinata,2005. Landasan Psikologi Proses Pendidikan. Bandung: Remaja Rosdakarya, Bandung.

Sumarno,dkk .1994. Suatu Alternatif Pengajaran Untuk Meningkatkan Kemampuan Pemecahan Masalah Matematika pada Guru dan Siswa SMP(Laporan Penelitian). Bandung: IKIP Bandung.

Surdjadi,2000. Kiat Pendidikan Matematika di Indonesia.Jakarta: Direktorat Jenderal Pendidikan Tinggi Depdiknas.

The Liang Gie,1988. Cara Belajar Yang Efisien. Yokyakarta: Gajah Mada University Press.

Udin, S. dkk. 1992. Materi Pokok Strategi Belajar Mengajar 1-9 PGMT. Jakarta: Universitas Terbuka. 